\title{
La regulación de las televisiones locales por ondas en Andalucía
}

\author{
Manuel Jesús Rozados Oliva \\ Profesor Asociado de Derecho Administrativo \\ Universidad de Cádiz
}

Sumario: I. INTRODUCCIÓN. II. MARCO JURÍDICO DE LA TELEVISIÓN LOCAL POR ONDAS EN EL DERECHO ESPAÑOL: LA LEY 41/1995, DE 22 DE DICIEMBRE: 1. Su aprobación y la falta de aplicación de su contenido. 2. Aspectos generales del modelo de televisión local por ondas. III. LA REGULACIÓN DE LAS TELEVISIONES LOCALES POR ONDAS EN EL DERECHO ANDALUZ: 1. La gestión de la televisión local por ondas: 1.1. La gestión municipal. 1.2. La gestión por particulares. 2. La concesión de servicio público de televisión local por ondas: 2.1. Procedimiento de otorgamiento. 2.2. Duración y extinción de la concesión. 3. La prestación del servicio de televisión local por ondas: 3.1. Los principios informadores de la actividad. 3.2. La regulación de los contenidos. 3.3. Régimen de la publicidad. 3.4. Otras obligaciones del concesionario. 4. La situación de las emisoras cuyo funcionamiento es anterior al 1 de enero de 1995. V. CONCLUSIONES.

\section{INTRODUCCIÓN}

En ocasiones observamos cómo aparecen fenómenos que no encuentran en el ordenamiento jurídico encaje alguno. En otras, vemos cómo las normas jurídicas nacen ajenas a la realidad que pretenden ordenar. Ambas situaciones convergen, sin duda, en la problemática de un medio de comunicación tan arraigado en nuestra vida cotidiana como la televisión local. Que esta modalidad televisiva es la gran asignatura pendiente en la efectiva ordenación de los medios audiovisuales en nuestro Derecho no es ninguna afirmación gratuita. A la ausencia de tratamiento legal durante los primeros quince años de su existencia ha seguido un período en el que, a pesar de contar con una ley estatal (Ley 41/1995, de 22 de diciembre) y con una serie de Decretos reguladores aprobados por aquellas Comunidades Autónomas que han optado por ejercer sus competencias en la materia ${ }^{1}$, la falta de desarrollo reglamentario de la norma estatal o, cuanto menos, la inactividad de la Administración del Estado en la planificación de las frecuencias radioeléctricas disponibles para el otorga-

\footnotetext{
${ }^{1}$ Las Comunidades Autónomas que han desarrollado sus competencias normativas son: Navarra (Decreto Foral 313/1996, de 9 de septiembre), Cataluña (Decreto 320/1996, de 1 de octubre) y Castilla - La Mancha (Decreto 54/2000, de 21 de marzo). A esta lista ha de añadirse la Comunidad andaluza, cuyo régimen jurídico es el objeto de este trabajo.
} 
miento de las concesiones de televisión local, han impedido que al día de hoy ésta se encuentre en las condiciones jurídicas que resultan exigibles desde el plano normativo.

El objeto de este trabajo, no obstante, no tiene como finalidad poner de manifiesto los problemas que plantea esta situación de precariedad jurídica y la necesaria reforma de una legislación que, en muchos de sus aspectos, se encuentra de espaldas a la realidad del sector, cuestiones ambas que ya han sido tratadas suficientemente en anteriores estudios ${ }^{2}$. La aprobación del Decreto 414/2000, de 7 de noviembre, de la Junta de Andalucía ${ }^{3}$, que regula el régimen jurídico de las televisiones locales por ondas en el ámbito de esta Comunidad Autónoma, su posterior reforma por vía del Decreto 27/2001, de 13 de febrero, y la convocatoria para la solicitud de concesiones de televisiones locales por ondas llevada a cabo por la Orden de 6 de febrero de $2001{ }^{4}$, son la muestra de una reciente preocupación por la regularización de este fenómeno en el marco de Andalucía, que, a nuestro juicio, ha de merecer las oportunas reflexiones.

Este interés se encuentra en directa relación con la importante implantación de la televisión local a lo largo de esta Comunidad. No en vano el nacimiento de esta modalidad televisiva en nuestro país tiene uno de sus orígenes en Andalucía ${ }^{5}$, siendo en esta zona del territorio nacional, junto con Cataluña y el Levante, donde se encuentra más extendida ${ }^{6}$. Desde el surgimiento de la misma hasta hoy el crecimiento del número de emisoras ha sido espectacular, encontrándonos en la actualidad en un vertiginoso proceso de incremento del número de televisiones locales como conse-

\footnotetext{
${ }^{2}$ El tratamiento monográfico de la televisión local por ondas y su régimen jurídico en nuestro Derecho puede verse en nuestra obra La televisión local por ondas, Comares, Granada, 2001. Ya centrándose en la legislación estatal sobre esta modalidad televisiva destacan las aportaciones de J. M. ${ }^{a}$ Souviron Morenilla, «En torno a la regulación de la televisión local por ondas y algunas cuestiones conexas», Revista de Estudios de la Administración Local y Autonómica, n. ${ }^{\circ} 269$, enero-marzo, 1996, y Derecho público de los medios audiovisuales: radiodifusión y televisión, Comares, Granada, 1999. También hay que reseñar el análisis de la ley estatal llevado a cabo por G. FernándeZ FARRERES, «La Televisión Local por Ondas Terrestres», en Ordenación de las Telecomunicaciones, Consejo General del Poder Judicial, Madrid, 1997 y El paisaje televisivo en España, Aranzadi, Madrid, 1997; así como la valoración de la misma realizada por R. DE CÁCERES Y CASILLAS, «La Ley de Televisión Local por Ondas Terrestres de 22 de diciembre de 1995», en Cremades (Coord.), Derecho de las Telecomunicaciones, La Ley - Ministerio de Fomento, Madrid, 1997.

${ }^{3}$ BOJA n. ${ }^{\circ} 139$, de 2 de diciembre de 2000.

${ }^{4}$ Ambas publicadas en BOJA n. ${ }^{\circ} 21$, de 20 de febrero de 2001.

${ }^{5}$ Sobre el origen de la televisión local en España y las causas que motivan su aparición, vid. M. J. Rozados Oliva, La televisión local por ondas, op. cit., p. 46 y ss.

${ }^{6}$ Ibidem, p. 49.
} 
cuencia de la penetración en el sector de los grandes grupos de comunicación ${ }^{7}$, hasta ahora ajenos al mismo. Buena prueba de todo ello puede ser la respuesta a la reciente convocatoria realizada por la Junta de Andalucía anteriormente mencionada, y a la que se han presentado más de 4.000 solicitudes ${ }^{8}$.

\section{MARCO JURÍDICO DE LA TELEVISIÓN LOCAL POR ONDAS EN EL DERECHO ESPAÑOL: LA LEY 41/1995, DE 22 DE DICIEMBRE}

\section{Su aprobación y la falta de aplicación de su contenido}

La ausencia de previsión en el ordenamiento jurídico para la creación de emisoras de televisión de ámbito local no fue obstáculo suficiente para evitar la aparición de éstas, en nuestro país, hace más de veinte años. Hay que tener en cuenta que la ley inicialmente destinada a la regulación de la televisión en nuestro Derecho, la Ley 4/1980, de 10 de enero, reguladora del Estatuto de la Radiodifusión y Televisión, se aprueba en un momento en que sólo existían dos cadenas de televisión pública de ámbito nacional, y no podía prever la eclosión que iba a producirse a lo largo de las dos últimas décadas en el sector audiovisual. La insuficiencia de este texto normativo para afrontar la regulación de las incipientes modalidades televisivas que iban surgiendo, bien como consecuencia de reivindicaciones políticas (las televisiones autonómicas), económicas (las televisiones privadas) o, simplemente, por la incorporación de los nuevos avances tecnológicos (el cable, el satélite, la transmisión digital), fue motivando que la respuesta a cada una de ellas se produjera particularizadamente, con la aprobación de cuerpos normativos ad hoc, de tal forma que, a diferencia de los países de nuestro entorno, se ha configurado en nuestro Derecho un ordenamiento jurídico de la comunicación audiovisual fragmentario y

\footnotetext{
${ }^{7}$ Además de la estrategia de expansión del grupo PRISA, que opera a través de la red LOCALIA TV con más de treinta emisoras, destacan igualmente los proyectos de los grupos Correo, Zeta y Prensa Española (vid. un interesante resumen de este «aterrizaje» en El País, 20 de mayo de 2001).

${ }^{8}$ El total de solicitudes admitidas es de 4.048, quedando fuera otras 204 por diversos motivos, principalmente la presentación fuera de plazo. Por municipios, en las provincias de Cádiz y Málaga la totalidad de los mismos han acudido a la convocatoria, siguiéndoles las provincias de Sevilla (83,3 por 100), Almería (67,6 por 100), Huelva (67,1 por 100), Jaén (61,5 por 100), Córdoba (61,3 por 100$)$ y Granada $(54,8$ por 100$)$. Estos datos permiten ver cómo la demanda se concentra en mayor medida en el litoral frente al interior, sobre todo en las provincias de Sevilla, Málaga y Cádiz, donde existe por otra parte una mayor implantación de esta modalidad televisiva (vid. El País, de 27 de mayo de 2001 y El Mundo, 6 de octubre de 2001).
} 
disperso, en el que cada modalidad televisiva posee su propia norma reguladora ${ }^{9}$.

En este contexto de dislate normativo, las emisoras de televisión local que iban surgiendo, fruto tanto de la iniciativa privada como de los propios municipios, se encontraron durante más de quince años en una situación de anomia, con el añadido de que la ausencia de encaje jurídico en cuanto a su creación no impedía a la Administración incoar los correspondientes expedientes sancionadores por la utilización de frecuencias radioeléctricas sin los oportunos títulos jurídico-administrativos habilitantes. A las continuas demandas del sector se unió los pronunciamientos del Tribunal Constitucional, que, en una jurisprudencia que se inicia con las SSTC 31/1994, de 31 de enero (referida a la televisión local por cable) y 88/1995, de 6 de junio (sobre la televisión local por ondas), pone de manifiesto la pasividad del legislador, reclamando del mismo la regulación de estas modalidades televisivas ${ }^{10}$.

Con el objeto de poner fin a esta situación se aprueba la Ley 41/1995, de 22 de diciembre, reguladora de la televisión local por ondas ${ }^{11}$. Su entrada en vigor debía acabar con el tan denunciado «caos» en las ondas provocado por la proliferación de numerosas emisoras clandestinas. Sin embargo, esta Ley nació marcada desde el principio. Durante su tramitación parlamentaria, el principal grupo de la oposición, que pocos meses después de su promulgación accedería al Gobierno de la Nación, manifestó su desacuerdo con la misma, ante lo cual dejó constancia de su expreso deseo de reformar el texto una vez en el poder. Esta promesa se materializó por medio del Proyecto de Ley de modificación de la LTLOT presentado en 1997, que hubo de ser retirado ante la falta del suficiente apoyo parlamentario para salir adelante. Esta oposición a los términos de la LTLOT por el actual Ejecutivo constituye una de las razones por las que éste, como advertíamos en el comienzo de este trabajo, no sólo no ha efectuado el necesario desarrollo reglamentario de dicho cuerpo legal,

\footnotetext{
${ }^{9}$ La reivindicación de la «televisión autonómica» motivó la aprobación de la Ley 46/1983, de 26 de diciembre, de regulación del Tercer Canal de Televisión. La misma respuesta individualizada surgiría para la mal llamada «televisión privada» (Ley 10/1988, de 3 de mayo), la televisión vía satélite (Ley 35/1992, de 22 de diciembre, sustituida por la Ley 37/1995, de 12 de diciembre, de Telecomunicaciones por Satélite, actualmente sólo en vigor en lo que respecta al servicio de televisión tras la derogación efectuada por la Ley 11/1998, de 24 de abril, General de Telecomunicaciones), la televisión local por ondas (Ley 41/1995, de 22 de diciembre) y, en último lugar, la televisión digital terrenal (RD 2169/1998, de 9 de octubre, por el que se aprueba el Plan Técnico de esta modalidad).

${ }^{10}$ Sobre la situación anterior a la aprobación de la ley estatal y los pronunciamientos del Tribunal Constitucional, vid. M. J. Rozados Oliva, La televisión local por ondas, op. cit., pp. 71-73.
}

${ }^{11}$ En adelante, LTLOT. 
sino que ni siquiera ha llevado a cabo una planificación de las frecuencias radioeléctricas disponibles para este servicio que hubiera permitido el otorgamiento de las correspondientes concesiones ${ }^{12}$.

Por todo ello, el estado de la cuestión, en la actualidad, es bastante desalentador. Han transcurrido seis años desde la aprobación de la LTLOT sin que ésta haya sido desarrollada por medio de los instrumentos necesarios, lo que produce que no hayan podido llevarse a cabo los procesos concesionales por las Comunidades Autónomas, que por tanto la referida Ley y el Derecho autonómico sobre la materia sigan sin poder aplicarse y que, en definitiva, las emisoras de televisión local continúen en la misma situación de precariedad jurídica, lo que por otra parte está permitiendo una proliferación masiva de emisoras que encuentran en esta situación de incertidumbre el escenario perfecto para desarrollar libremente sus planteamientos empresariales, políticos, o ambos, sin sujetarse a las reglas contenidas en normas que se encuentran vigentes y que se corresponden en su mayor parte con las que presiden la ordenación de la comunicación audiovisual en nuestro Derecho.

\section{Aspectos generales del modelo de televisión local por ondas}

Sin entrar en un análisis detallado del conjunto de cuestiones que conforman el marco jurídico al que ha de someterse esta modalidad televisiva en nuestro Derecho, resulta necesario exponer, del modo más resumido posible, los principales aspectos sobre los que se construye el mismo. Así, el artículo 11 LTLOT define a la televisión local por ondas como «aquella modalidad de televisión consistente en la emisión o transmisión de imágenes no permanentes dirigidas al público sin contraprestación económica directa por medio de ondas electromagnéticas propagadas por una estación transmisora terrenal en el ámbito territorial señalado en el artículo 3 de esta Ley». De ello se desprende, a juicio de SOUVIRON ${ }^{13}$, que se trataría de una modalidad de televisión que vendría definida por los elementos de

\footnotetext{
${ }^{12}$ La posición del Ejecutivo en esta cuestión ha ido evolucionando. Mientras hace tan sólo un año continuaba manifestándose partidario de una reforma legislativa, ya no sólo sobre esta modalidad televisiva, sino sobre el conjunto del sector audiovisual, anunciando la presentación en la primavera de 2001 de un Proyecto de Ley a tal fin (vid. El Mundo, de 2 de diciembre de 2000), pocos meses después parecía optar por la definitiva planificación de frecuencias disponibles para las emisoras de televisión local, pero esta vez en el marco de la implantación de la tecnología digital a la televisión (vid. Gaceta de los negocios, 8 de marzo de 2001), compromiso que hasta el momento de redactar estas líneas no se ha hecho efectivo.

13 Vid. J. M. Souviron Morenilla, «En torno a la regulación de la televisión local por ondas y algunas cuestiones conexas», en Revista de Estudios de la Administración Local y Autonómica, n. ${ }^{\circ} 269$, enero-marzo, 1996, pp. 54-55.
} 
base de su caracterización como tal (emisión o transmisión de imágenes no permanentes dirigidas al público), a los que se sumarían los elementos específicos relativos a su forma de emisión (ondas hertzianas terrestres) y a su ámbito de cobertura (local), sin olvidar el carácter de medio audiovisual de comunicación social circunscrito a la esfera local ${ }^{14}$.

A ello habría que sumar, a nuestro juicio, otras dos notas relevantes. En primer lugar, que la puesta a disposición de imágenes no permanentes ha de realizarse sin contraprestación económica alguna, lo cual introduce una nota de gratuidad en la prestación del servicio, impidiendo con ello la posibilidad de imponer ningún gravamen a los usuarios del mismo. Con ello, en definitiva, se impide el desarrollo de una televisión local de pago o de abono.

Y, en segundo lugar, el carácter de medio de comunicación social le confiere un papel importante en el desarrollo de los intereses locales, como así reconoce la propia LTLOT, al incluir, entre los principios inspiradores que deben presidir la prestación de este servicio, «la promoción de los intereses locales, impulsando para ello la participación de grupos sociales de tal carácter, con objeto de fomentar, promover y defender la cultura y convivencia locales» [art. 6.g) LTLOT]. Realmente, este principio constituye el principal argumento que legitima la reivindicación de una televisión independiente y autónoma del resto, al resaltar el valor de la televisión como medio que sirve de cauce para la vertebración de la sociedad local, así como el mantenimiento y promoción de unos valores estrictamente locales que, de otro modo, no gozarían de la posibilidad de ser difundidos por otras modalidades de televisión.

Este factor condiciona, por tanto, el diseño de los contenidos de la programación. A este respecto, podríamos afirmar que la sujeción a este principio supone la adopción de un modelo híbrido entre la televisión temática y la generalista. Podríamos considerar que se trata de una televisión temática por cuanto la estructura de la programación ha de tener como elemento nuclear lo local, con independencia de la variedad en el tratamiento del mismo (informativos, concursos, documentales, debates...). Ahora bien, a nuestro juicio, la preeminencia del carácter local no es incompatible con la oferta de una programación más amplia que incluya otro tipo de productos (el ejemplo más claro lo constituirían las películas), puesto que el impulso y fomento de la cultura y convivencia local no

14 Ibidem, p. 55. En este sentido, también De CÁCERES, «La Ley de Televisión Local por Ondas de 22 de diciembre de 1995», en Derecho de las Telecomunicaciones (coord. J. Cremades), La Ley-Ministerio de Fomento, Madrid, 1997, p. 588. 
se impone en términos de exclusividad, sino de prioridad. Por ello entendemos que sería más correcto hablar de la televisión local por ondas, en su configuración legal, como una televisión generalista cuya característica principal se centra en el tratamiento predominante de los temas locales. Esta cuestión posee una trascendencia notable, pues a nuestro juicio el modelo que se contempla impide la existencia de emisoras locales temáticas, salvo que su programación gire sobre algún tema característico de la vida en la localidad.

Por otro lado, el artículo 2 LTLOT atribuye a la televisión local por ondas la naturaleza de servicio público. El debate acerca de la idoneidad de esta publicatio fue el principal punto de fricción en la tramitación parlamentaria de este texto que, además, conecta con una controversia ya arraigada en nuestra doctrina administrativista: el carácter de servicio público de la televisión ${ }^{15}$. La vertebración de esta categoría jurídica en el marco de los medios audiovisuales, abocada a una redefinición tarde o temprano, añade en este caso nuevos problemas, como la titularidad del servicio o su obligatoriedad, cuya profundización nos alejaría del objeto de este trabajo ${ }^{16}$.

Otras dos medidas relevantes resultan de la limitación del número de emisoras por cada ámbito de cobertura y la fijación de este último. Por lo que respecta a la primera cuestión, se observa una injustificada limitación contenida en el artículo 4 LTLOT, al prever tan sólo una emisora por ámbito de cobertura, reconociendo la posibilidad de incrementar a dos las concesiones cuando resulte compatible con las necesidades del espectro radioeléctrico, lo que ha sido reconocido por el Derecho autonómico al disponer un número máximo de dos concesiones ${ }^{17}$. Sin duda, es bastante difícil encontrar una justificación a tal limitación, sobre la que no puede

\footnotetext{
${ }^{15}$ Se trata ésta de una polémica viva a la que han contribuido numerosos trabajos que abordan la publificación de la actividad televisiva desde todos los perfiles posibles, llegando, por tanto, a soluciones dispares que se dividen, básicamente, entre aquellas que abogan por el mantenimiento de dicha calificación y quienes sustentan, de contrario, la necesidad de superar la pervivencia de esta categoría, al menos en los términos actuales. Esta discusión, como es lógico, no es ajena al verdadero debate sobre la evolución dogmática del servicio público en nuestro Derecho administrativo. La referencia bibliográfica, tan sólo en lo que respecta a esta cuestión en el seno de la ordenación de la televisión, es sumamente exhaustiva, por lo que nos remitimos a la recogida en nuestro trabajo $L a$ televisión local por ondas, op. cit., pp. 162-167.

${ }^{16} \mathrm{Vid}$. al respecto las diferentes posiciones doctrinales, incluida la nuestra, en M. J. RozAdos OLIVA, Las televisiones locales por ondas, op. cit., pp. 232-236.

17 Vid. artículo 4.2 Decreto 414/2000, de 7 de noviembre, de Andalucía, artículo 6.5 Decreto 54/2000, de 21 de marzo, de Castilla La-Mancha, artículo 8.1 Decreto Foral 313/1996, de 9 de septiembre, de Navarra y artículo 6.4 Decreto 320/1996, de 1 de octubre, de Cataluña.
} 
invocarse la tan manida «escasez» del espectro. Hubiera bastado, como preveía el Proyecto de Ley de reforma de 1997, la cláusula de remisión a las disponibilidades del espectro radioeléctrico para permitir la instalación de cuantas televisiones locales fueran solicitadas, si así lo permite la ordenación técnica de las frecuencias. Con ello sólo se consigue facilitar una situación monopolística que no parece poseer mucho sentido si, por otro lado, se pretende fomentar la competencia en el mercado audiovisual. Que sólo exista una televisión local en una población pequeña es algo que no ha de depender de limitaciones jurídicas, ya que muy probablemente sea insostenible un número mayor de operadores. Ahora bien, no parece que pueda ser objeto del mismo tratamiento este caso con las circunstancias de otro municipio en el que viven cientos de miles de personas o incluso millones.

En cuanto al ámbito de cobertura, éste habrá de limitarse, según el artículo 3.1 LTLOT, al núcleo urbano principal de población del Municipio correspondiente, con la posibilidad de su ampliación a otros núcleos de población cuando lo aconseje el número de habitantes, pudiendo instalarse estaciones reemisoras siempre que lo permita el espectro radioeléctrico (art. 3.2 LTLOT). Esta ampliación ha de considerarse distinta de la establecida en el apartado $3 .^{\circ}$ del artículo 3 LTLOT, que se refiere a la posibilidad de que la cobertura alcance a otros municipios, estableciéndose que en este caso ha de tener carácter excepcional y sujetarse a los mismos límites para la emisión en cadena previstos en el artículo 7.4 LTLOT.

Ciertamente, habría que destacar el exceso de celo en la delimitación del ámbito de cobertura, que choca sin embargo de manera frontal con las circunstancias técnicas, pues es prácticamente imposible que una emisión por ondas hertzianas cubra zonas del territorio definidas tan estrictamente como dispone la Ley. Por otro lado, parece incomprensible que la cobertura de la misma deba ceñirse, con carácter general, al núcleo urbano principal, y no a todo el territorio municipal ${ }^{18}$. A ello ha de sumarse el discutible tratamiento sin distinción según la dimensión espacial y poblacional de cada municipio ${ }^{19}$.

\footnotetext{
${ }^{18}$ En esta línea de crítica, en cuanto a lo irrazonable y restrictivo de la medida, se manifiesta igualmente R. De CÁceres y CAsillas, «La Ley de Televisión Local por Ondas», en J. Cremades, (coord.), Derecho de las Telecomunicaciones, La Ley-Ministerio de Fomento, Madrid, 1997, pp. 591-592, para quien, ciertamente, es difícilmente controlable además desde el punto de vista técnico.

19 Así, para Fernández Farreres (El paisaje televisivo en España, Aranzadi, Pamplona, 1997, p. 103), este criterio es una manifestación del tradicional principio de uniformidad en el tratamiento de las entidades municipales que, no obstante, no reconoce la diversidad en cuanto a la extensión de los diferentes municipios y la utilización del espectro radioeléctrico.
} 
No obstante, esta rigidez en las disposiciones de la Ley en cuanto a la extensión de las emisiones, precisamente por la dificultad de su ajuste por motivos técnicos, no impedirá que, en la práctica, las emisiones locales alcancen una cobertura superior no sólo al núcleo urbano principal del término municipal, sino incluso a poblaciones circundantes a éste.

La gestión del servicio podrá ser realizada por el propio Municipio, que gozará de un derecho de preferencia al respecto, o por personas naturales o jurídicas. En cualquier caso, corresponderá al órgano autonómico el otorgamiento de las concesiones que habiliten la prestación del mismo. Para ello, el procedimiento a seguir, resumidamente, es el siguiente (arts. $10 \mathrm{y}$ 11 LTLOT): primero, han de preverse las frecuencias radioeléctricas disponibles mediante una reserva provisional de las mismas que ha de realizar la Administración del Estado; con esta previsión puede el órgano autonómico llevar a cabo los respectivos procesos concesionales; finalizados estos últimos, se asignarán definitivamente las frecuencias radioeléctricas a aquellos que hubieran obtenido las referidas concesiones.

\section{LA REGULACIÓN DE LAS TELEVISIONES LOCALES POR ONDAS EN EL DERECHO ANDALUZ}

La incertidumbre sobre la reforma de la LTLOT, unido a las dificultades de consensuar con los diferentes interesados (Administraciones locales y empresarios del sector) los términos en que había de pronunciarse la futura norma reguladora, habían postergado la aprobación de ésta en la Comunidad andaluza. En vista de que la pretendida reforma no tiene visos de acometerse y con la esperanza que, de un modo u otro, algún día tendrá que regularizarse esta situación, el Gobierno autonómico decidió, no sólo aprobar el instrumento normativo necesario para completar el marco jurídico de las televisiones locales por ondas en el ámbito de Andalucía (Decreto 414/2000, de 7 de noviembre ${ }^{20}$ ), sino incluso abrir la correspondiente convocatoria (Orden de 7 de febrero de 2001), haciendo efectivas las competencias atribuidas a tal efecto en el artículo 16 del

\footnotetext{
En cuanto a la dimensión poblacional, para De CACERES ( «La Ley de Televisión Local por Ondas Terrestres», en J. CREMADES, Derecho de las Telecomunicaciones, op. cit., pp. 591-592), la falta de indeterminación de un número mínimo de habitantes para el establecimiento de una televisión local provoca que se pase de una situación de prohibición al reconocimiento de tantas televisiones locales como municipios hay en España. En la misma línea se pronuncia Souviron (Derecho público de los medios audiovisuales: radiodifusión y televisión, Comares, Granada, 1999, p. 253) al criticar que se otorgue el mismo tratamiento a un municipio de 15.000 habitantes que a otro de tres millones.

${ }^{20}$ En adelante, DATLO.
} 
Estatuto de Autonomía ${ }^{21}$. Aunque tanto las determinaciones de la LTLOT como las que derivan de estas normas autonómicas no sean objeto de aplicación por las razones que ya hemos expuesto, lo cierto es que constituyen el Derecho vigente sobre esta modalidad televisiva al que, salvo reforma, habrá de sujetarse la futura regularización del sector, motivo por el cual consideramos de interés detenernos en el contenido de este régimen jurídico. Por otra parte, el Decreto andaluz viene a reproducir las determinaciones de la LTLOT, siguiendo la línea marcada por anteriores normas autonómicas (especialmente los Decretos catalán y castellano-manchego), sin aportar significativas novedades en muchos aspectos de su competencia en los que podría haber entrado, como advertiremos en su momento.

\section{La gestión de la televisión local por ondas}

Conforme al modelo consagrado en la LTLOT, puede ésta realizarse mediante dos formas: por el propio Municipio o por personas naturales o jurídicas, con o sin ánimo de lucro (arts. 5 LTLOT y 4 DATLO). Lo destacable en este caso es el reconocimiento de una preferencia del Municipio para la gestión del servicio, de tal modo que sólo la renuncia del mismo a la gestión directa permite que la prestación sea llevada a cabo por un empresario privado (arts. 9 LTLOT y 4 DATLO) ${ }^{22}$. Ha de tenerse en cuenta, no obstante, que el máximo de emisoras por ámbito de cobertura es de dos, lo que permitiría, en aquellos casos en que el Municipio optara por gestionar por sí mismo el servicio, la entrada de un empresario privado.

${ }^{21}$ Artículo 16 E.A. Andalucía:

«1. En el marco de las normas básicas del Estado, corresponde a la Comunidad Autónoma de Andalucía el desarrollo legislativo y la ejecución del régimen de radiodifusión y televisión en los términos y casos establecidos en la Ley que regula el Estatuto Jurídico de la Radio y Televisión.

2. Igualmente le corresponde, en el marco de las normas básicas del Estado, el desarrollo legislativo y la ejecución del régimen de Prensa y, en general, de todos los medios de comunicación social.

En los términos establecidos en los apartados anteriores de este artículo, la Comunidad Autónoma de Andalucía podrá regular, crear y mantener su propia televisión, radio y prensa y, en general, todos los medios de comunicación social para el cumplimiento de sus fines.»

${ }^{22}$ Esta preferencia ha sido criticada por De CÁCERES ( «La Ley de Televisiones Locales por Ondas Terrestres», en J. CREMADES, - Coord.-, Derecho de las Telecomunicaciones, p. 592), para quien además de resultar contrario, a su juicio, al libre mercado y a la libre competencia, puede facilitar la manipulación de las emisoras por los gobernantes municipales, haciendo de ellas un instrumento de propaganda partidista, y sometiendo a los trabajadores a la inseguridad en sus puestos de trabajo derivada de los cambios en el gobierno municipal. 


\subsection{La gestión municipal}

En los casos en que el Municipio haga efectiva su opción preferente a la gestión del servicio, la misma habrá de hacerse mediante alguna de las formas previstas en el artículo 85.3 LBRL, es decir, por el propio ente local, por organismo autónomo o sociedad mercantil cuyo capital pertenezca íntegramente a la entidad local (art. 5 LTLOT y art. 8.1 DATLO). La elección del modo de organización final de la prestación del servicio, de las fórmulas posibles, es potestad que corresponde al ente local (SosA WAGNER) ${ }^{23}$. Cualquiera que sea el modo de gestión municipal del servicio, el control del mismo corresponderá al Pleno, que deberá velar por el cumplimiento de las obligaciones y, básicamente, de los principios a que se sujeta esta actividad (arts. 12 LTLOT y 8.3 DATLO).

En cuanto a la financiación, se trata de uno de los aspectos discutidos del régimen jurídico de esta modalidad televisiva en el que, a pesar del desacuerdo entre las partes afectadas, no se ha llegado sin embargo a alcanzar los niveles de polémica que se han producido sobre la doble financiación de las televisiones de cobertura nacional ${ }^{24}$. La LTLOT obvió un pronunciamiento a este respecto que hubiera sido deseable, como ha puesto de manifiesto SoUVIRON ${ }^{25}$, omisión que de nuevo viene a producirse en la norma andaluza, lo que permite que la televisión gestionada por el propio Municipio pueda financiarse a través de una doble vía, pública y privada.

23 Vid. F. Sosa Wagner, La gestión de los servicios públicos locales, Civitas, Madrid, 1992, p. 48.

${ }^{24}$ Los problemas en orden a la diferente posición en el mercado de las televisiones públicas y las privadas, en función del privilegio de las primeras al poseer una doble vía de financiación como consecuencia de la compatibilización de los ingresos derivados de las arcas públicas con los provenientes del mercado publicitario, ha sido objeto de una clásica polémica, como se pone de manifiesto en numerosos trabajos, de los que deben destacarse las aportaciones de Fernández Farreres ( $E l$ paisaje televisivo en España, Aranzadi, Pamplona, 1997) y MuÑoz Machado (Público y privado en el mercado europeo de la televisión, Civitas, Madrid, 1993). Sobre la cuestión, vid. también las reflexiones de DE LA QuAdRA-SALCEDo («Informe preliminar sobre el régimen jurídico del audiovisual», pp. 38 y ss.), así como las de MALARET y MuÑoz Machado (bajo el título común de «La financiación de la televisión pública y privada»), todas ellas en la obra El régimen jurídico del audiovisual, Marcial Pons, Institut d'Estudis Autonòmics, Madrid, Barcelona, 2000. Además, vid. los trabajos de BUHIGAS ARIZcun («La financiación de las televisiones públicas en España») y CARRO MARINA («La aplicación de la regulación europea sobre ayudas públicas en la financiación de las empresas públicas de televisión. El caso español»), ambos en S. MuÑoz Machado, (Ed.), Derecho Europeo del Audiovisual, Escuela Libre Editorial, Madrid, 1997; F. Falcón y Tella, «La doble financiación de las televisiones públicas en España desde la óptica del Derecho de la competencia», en Revista Aragonesa de Administración Pública, n. ${ }^{\circ}$ 8, 1996; J. C. Laguna de Paz, Televisión y competencia, La Ley, Madrid, 2000, pp. 326 y ss.

25 Vid. J. M. Souviron Morenilla, Derecho público de los medios audiovisuales, Comares, Granada, 1999, p. 254. 


\subsection{La gestión por particulares}

\section{a) Requisitos exigibles al concesionario}

Para optar al otorgamiento de una concesión de televisión local por ondas, la LTLOT establece una serie de condiciones especiales que ha de reunir el solicitante, en el caso de que la gestión vaya a ser llevada a cabo por particulares. A diferencia del régimen previsto para los concesionarios de televisiones hertzianas de cobertura nacional, para los que se impone la obligación de que la personalidad jurídica del solicitante revista la forma de sociedad mercantil (art. 18 Ley 10/1988, de 3 de mayo, de Televisión Privada), se admite en este caso que el servicio sea prestado por personas naturales o jurídicas, y no sólo sociedades mercantiles. Los requisitos establecidos en el artículo 13 LTLOT, reproducidos por el artículo 9 DATLO, son los siguientes:

1. En cuanto a la nacionalidad, en el caso de personas naturales, habrán de poseer la nacionalidad española o comunitaria y, en cuanto a las sociedades y entidades sin ánimo de lucro, la nacionalidad española.

2. En el caso de sociedades, su objeto social deberá incluir la gestión indirecta de este servicio de televisión. Las acciones de estas sociedades serán nominativas y la participación en su capital de personas que no sean nacionales de algún Estado miembro de la Unión Europea no podrá superar directa o indirectamente el 25 por 100 de su cuantía.

A ellos se añaden por el artículo 9 DATLO la obligación de tener capacidad para contratar y no estar incurso en las prohibiciones contempladas en el Texto Refundido de la Ley de Contratos de las Administraciones Públicas (Real Decreto Legislativo 2/2000, de 16 de junio) ${ }^{26}$ y una serie de causas de exclusión que podemos sistematizar de la siguiente forma:

1. Participar en más de una concesión, ya sea como titular o mediante vínculos societarios con entidades concesionarias. La preocupación de la norma andaluza se manifiesta en este caso doblemente, pues mientras que el artículo 9.1.c).4 DATLO dispone que la sociedad concesionaria «no podrá estar participada mayoritariamente, de forma directa o indirecta, por ningún accionista que a su vez participe de dicha forma en otra sociedad concesionaria», el artículo 9.3 DATLO establece que «en ningún caso podrá ser concesionario el que sea titular de otra concesión de televisión local por ondas terrestres o participe mayoritariamente, de

26 En adelante, TRLCAP. 
forma directa o indirecta, en otra sociedad concesionaria, dentro del territorio de la Comunidad Autónoma de Andalucía».

2. Haber perdido la condición de concesionario como consecuencia de la comisión de una infracción administrativa calificada como muy grave o haber participado en un porcentaje superior al 10 por 100 en una sociedad concesionaria sancionada por tal motivo [art. 9.2.a) DATLO], supuesto que impide no sólo ser titular de una concesión, sino incluso participar en más de un 10 por 100 en una sociedad concesionaria.

3. Por último, se incluyen otras dos prohibiciones: de un lado, se impide ser concesionario a quien incurra "en alguno de los supuestos de emisión en cadena a los que se refieran los apartados 2 y 3 del artículo 6 de este Decreto» (art. 9.4 DATLO), y, de otro, no podrá ser titular de una concesión o participar en más de un 10 por 100 en una sociedad concesionaria «aquella persona que hubiera sido sancionada, mediante resolución administrativa firme, como responsable de la comisión de una infracción muy grave por la prestación del servicio de televisión local por ondas terrestres sin la correspondiente concesión, o que participara en un porcentaje superior al 10 por 100 en una sociedad que hubiera sido sancionada por la comisión de dicha infracción» [art. 9.2.b) DATLO].

El alcance de este último supuesto es lo suficientemente trascendente como para dedicar alguna reflexión sobre el mismo. En principio, de su contenido puede colegirse que, en el ámbito de la Comunidad Autónoma de Andalucía, todos los operadores privados que se encuentran emitiendo en la actualidad corren el riesgo de encontrarse imposibilitados no sólo para la obtención de las futuras concesiones, si son objeto de un expediente administrativo sancionador por la realización de las emisiones sin contar con la preceptiva concesión, sino incluso para participar accionarialmente en un potencial concesionario. La adopción de este criterio podría quedar justificada desde la base de penalizar a quien ha desarrollado una actividad de modo ilegal, no sometiéndose al régimen jurídico establecido y, por tanto, funcionando sin los oportunos títulos habilitantes. Sin embargo, hay que recordar que, hasta el momento, no existe ninguna televisión que opere con la oportuna concesión, lo que viene a significar que la excepcionalidad que supondría la emisión clandestina viene a ser la regla absoluta.

Se produce con ello, además, una situación discriminatoria, pues coloca en una posición aún más precaria a los operadores privados con relación a los municipios que, obviamente, no se verían afectados por la citada prohibición, aun siendo incluso susceptibles del mismo expediente ad- 
ministrativo. Si a todo ello unimos el reconocimiento del ejercicio de la potestad sancionadora por el órgano autonómico y la posibilidad de que éste desarrolle dicha potestad de modo selectivo, frente a unos emisores y no frente a todos ${ }^{27}$, creemos que no es necesario describir a qué resultados podría llegarse con una torticera utilización de estos instrumentos.

b) La prohibición de formar parte de una cadena de televisión

Las medidas limitadoras sobre la personalidad del concesionario particular no alcanzan solamente a las condiciones para contratar expuestas anteriormente. Con la finalidad de potenciar la identidad propia de cada emisora de televisión y garantizar con ello su autonomía e independencia se introduce un nuevo elemento: la prohibición de pertenencia del aspirante a una cadena de televisión (arts. 7 LTLOT y 6 DATLO) ${ }^{28}$. El objetivo se encuentra, principalmente, en la intención de evitar el riesgo de la formación de cadenas de televisión que operen a nivel supralocal, incluso a nivel nacional, y que sean el resultado de una agrupación de televisiones locales.

El criterio adoptado para considerar la pertenencia a una cadena de televisión es que exista una unidad de decisión, entendiendo que la misma se produce «en todo caso, cuando uno o varios socios, mediante la agrupación de acciones, ejerzan la administración de dos o más sociedades gestoras del servicio, posean en éstas la mayoría de los derechos de voto, o tengan derecho a nombrar o destituir a la mayoría de los miembros de sus respectivos consejos de administración» (arts. 7.2 LTLOT y 6.2 DATLO), siguiendo la regla de la limitación accionarial o el control societario, adoptada para otras modalidades de televisión, como advierte GONZÁLEZ ENCINAR, para quien la eficacia de esta medida ha de ponerse en duda desde el momento en que no se tienen en cuenta otras formas de control de una emisora de televisión, como el suministro de programación o financiación, o el establecimiento de cláusulas contractuales 29.

\footnotetext{
${ }^{27}$ Circunstancia que no resulta infrecuente, como ya se encargó de denunciar NiETo al significar la «arbitrariedad en la persecución» en la que a menudo incurre la Administración (Derecho Administrativo Sancionador, Civitas, 2. ${ }^{\mathrm{a}}$ ed., 1994, p. 25).

${ }^{28}$ La falta de limitación en este sentido, a juicio de LaGuna («La concentración en los medios de comunicación social», en El Derecho Administrativo en el umbral del siglo XXI. Homenaje al Prof. Martín Mateo, Tirant lo Blanch, Valencia, 2000, p. 2836), subvertiría su verdadero carácter de televisión local.

29 Vid. J. J. GonZÁLez Encinar, «Modelos comparados de regulación de lo audiovisual», en El régimen jurídico de lo audiovisual, Marcial Pons, Institut d’Estudis Autonòmics, Madrid-Barcelona, 2000, pp. 102-106.
} 
La introducción de esta limitación que alcanza a la gestión del servicio por particulares sólo encontraría justificación desde la óptica de un mayor reforzamiento del carácter local de la emisora de televisión. No puede interpretarse, obviamente, como una medida tendente a posibilitar una mayor competencia en el mercado, puesto que la propia restricción en cuanto al número de emisoras conlleva una inevitable reducción de la oferta ${ }^{30}$. Por otro lado, el fortalecimiento de dicho carácter local sólo puede llevarse a efecto a través de la imposición de una serie de reglas en orden a los contenidos de la programación, como de hecho así ocurre con los límites establecidos para la emisión en cadena de programas. La formación de cadenas de televisión local permitiría a los operadores privados asegurar la subsistencia de su oferta televisiva con la reducción de los costes de organización empresarial y producción de programas, sin que ello deba ir en detrimento de la «identidad local» de cada emisora, razones por las cuales entendemos que estamos ante una medida cuya imposición carece de suficiente razonabilidad y que, además, choca con la propia dinámica del sector, que tiende, como ya vimos, a posibilitar la agrupación de emisoras locales de televisión.

\section{La concesión de servicio público de televisión local por ondas}

\subsection{Procedimiento de otorgamiento}

Conforme al artículo 7 DATLO, corresponde al Consejo de Gobierno, a propuesta del Consejero de la Presidencia, el otorgamiento de la concesión, tanto en aquellos casos en que la gestión vaya a ser llevada a cabo por el propio Municipio como en aquellos otros en que sean personas naturales o jurídicas los definitivos adjudicatarios. Para ello, se prevé en los artículos 10-17 DATLO un procedimiento que se estructura en dos fases:

a) Fase de solicitud: Se inicia con la apertura de una convocatoria en la que deberán participar todos aquellos interesados en la prestación del servicio de televisión local por ondas (municipios y personas naturales o jurídicas). Con ello se opta, coherentemente, por un modelo procedimen-

\footnotetext{
${ }^{30}$ En este punto es curioso destacar, como advierte GonZÁlez EnCINAR (ibidem, p. 103), el tratamiento discriminatorio, en términos de defensa de la competencia y garantía del pluralismo, que se produce en el caso de las televisiones locales por ondas, pues «mientras el Legislador español entiende que atentaría contra el pluralismo el que una misma persona fuese a la vez propietaria, por ejemplo, de una televisión local por ondas en Jerez de la Frontera y otra en Monforte de Lemos, al Legislador español no parece preocuparle el que un mismo grupo empresarial pueda tener, como alguno tiene, a la vez, una concesión de televisión nacional por ondas, una plataforma de satélite, una pluralidad de periódicos, varias cadenas de radio, derechos de exclusiva sobre fútbol y películas y el control de un sistema de acceso condicional».
} 
tal que se caracteriza porque la iniciativa parte de la propia Comunidad Autónoma que, ante las solicitudes presentadas, puede de este modo trasladar a la Administración estatal las necesidades de frecuencias en su ámbito territorial para que esta última lleve a cabo la previsión de las disponibles atendiendo a la demanda real. Cabría la posibilidad de que, al contrario, fuera la Administración estatal la que previamente fijara las frecuencias disponibles y, en función de las mismas, el órgano autonómico pusiera en marcha los procesos concesionales. Sin embargo, en este caso podría darse un desfase entre la demanda real de emisoras y la previsión estatal, lo que se traduciría, en definitiva, en un diseño del mapa audiovisual forzado.

b) Fase de adjudicación: Una vez obtenida de la Administración estatal la reserva provisional de las frecuencias disponibles, así como las características técnicas sobre las que habrán de realizarse las emisiones (potencia, radiación, etc.), se abre una nueva convocatoria en la que deben participar todos aquellos presentes en la anterior (art. 13.1 DATLO). En esta segunda fase se produce, como es lógico, un diferente tratamiento según la gestión vaya a ser municipal o privada, siguiéndose en este segundo caso el procedimiento de concurso público (art. 13.2 DATLO). Corresponderá al Consejero de la Presidencia la propuesta de adjudicación provisional de las concesiones, que deberá resolver el Consejo de Gobierno, atendiendo para ello a la viabilidad técnica y económica de las solicitudes, las garantías sobre el cumplimiento de los principios inspiradores de esta modalidad televisiva y la observancia de los demás requisitos conforme a la legislación vigente (art. 14 DATLO). Para la valoración de estos extremos, y por tanto la selección de las solicitudes que deben ser estimadas, se incluyen una serie de criterios en el artículo 15 DATLO, tratándose, en general, de elementos de juicio cuya aplicación resulta justa y razonable ${ }^{31}$, aunque se recoge en último lugar una cláusula en virtud

31 Estos criterios son los siguientes:

«a) El interés cultural o educativo del proyecto, valorando esencialmente el fomento de las diferentes manifestaciones de la cultura local y andaluza.

b) La promoción de la diversidad etnográfica y social dentro del ámbito territorial de cobertura, especialmente a través de la participación de los grupos sociales más significativos.

c) La creación de emisoras que realicen su programación en municipios con población dispersa en núcleos aislados, cuando su puesta en marcha suponga un factor de integración territorial y de conocimiento de los servicios públicos.

d) La viabilidad del proyecto y las garantías de continuidad en la prestación del servicio.

e) La capacidad profesional y experiencia de los solicitantes, en aras del mayor cumplimiento de los principios inspiradores establecidos en el artículo 5 de este Decreto.

f) El compromiso de realizar una programación que sobrepase los mínimos establecidos en los artículos 18 y 19 de este Decreto. 
de la cual podrán tenerse en cuenta otros méritos «que, a la vista de la documentación presentada, sean considerados especialmente relevantes». No nos parece necesario, a la luz de la exhaustividad de la lista de elementos valorativos, introducir un criterio que incrementa injustificadamente la discrecionalidad del órgano competente para evaluar las solicitudes.

Aquellos que resulten adjudicatarios provisionalmente de las concesiones habrán de presentar al órgano autonómico un proyecto técnico de las instalaciones que deberá ser aprobado por éste, disponiendo de un plazo máximo de doce meses para la ejecución del mismo. Una vez realizada, habrá de obtenerse la conformidad por la Dirección General de Comunicación Social, procediéndose a continuación a la adjudicación definitiva de la concesión (arts. 16 y 17 DATLO).

\subsection{Duración y extinción de la concesión}

Es característico del contrato de gestión de servicios públicos la prohibición de que el mismo posea un carácter indefinido [art. 157.b) TRLCAP]. A tal efecto, la LTLOT, a la que se remite el artículo 23.1 DATLO, estableció en su artículo 14 un período máximo de cinco años, aspecto éste que ha sido objeto de crítica, principalmente por ser un plazo excesivamente corto, lo que introduce un obstáculo de consideración para la futura rentabilidad económica de la explotación ${ }^{32}$, y ser injustificadamente discriminatorio en relación al previsto para los concesionarios

g) La prestación correcta del servicio, cuando se trate de solicitantes que han sido concesionarios anteriormente de un medio de comunicación social. Se entenderá correcta la prestación del servicio cuando el concesionario haya dado cumplimiento a los compromisos concesionales y no haya sido sancionado por alteraciones de los parámteros técnicos asignados.

h) Compromiso de desarrollar programas de formación ocupacional y de fomento de la creación de empleo.

i) Compromiso de tener su domicilio social y su centro principal de actividad en el ámbito territorial de la emisora objeto de la concesión.

j) La carencia de ánimo lucrativo en los fines de la entidad solicitante.

k) Compromiso de mantener en su plantilla el mayor número posible de discapacitados, por encima del 2 por 100 previsto en el Real Decreto Legislativo 2/2000, de 16 de junio, por el que se aprueba el Texto Refundido de la Ley de Contratos de las Administraciones Públicas.

1) Otros que, a la vista de la documentación presentada, sean considerados especialmente relevantes.»

32 Vid. R. De CÁCeres y CASIllas, «La Ley de Televisiones Locales...», op. cit., p. 595; J. C. Laguna de Paz, Régimen jurídico de la televisión privada, pp. 240-241; J. M. a Souviron Morenilla, Derecho público de los medios audiovisuales, Comares, Granada, 1999, p. 254. 
de televisión hertziana de cobertura nacional, cuya duración es de diez años (art. 11 LTP).

A la finalización del mismo, se recoge la posibilidad de una prórroga, sometiendo la eficacia de la misma a la existencia de una previa solicitud del interesado, que deberá formularse con tres meses de antelación (art. 23.1 DATLO). Para su otorgamiento será necesaria la emisión de un informe favorable por la Administración del Estado, debiendo atender el mismo a las disponibilidades del espectro radioeléctrico, de otras necesidades y usos de éste y al desarrollo de la televisión por cable, pudiendo en función de dichos elementos renovar la asignación de frecuencia otorgada o la asignación de una nueva (art. 14 LTLOT). Siendo razonables los elementos que condicionan la prórroga de la concesión en relación al aprovechamiento del espectro radioeléctrico, no parece, sin embargo, justificable que la pervivencia de la misma haya de someterse al desarrollo de la televisión por cable. Probablemente el legislador pensaba que el desarrollo de las infraestructuras de cable y la oferta de contenidos audiovisuales llevaría a la desaparición de la televisión hertziana, sobre todo en el ámbito local. No creemos que, en términos de razonabilidad, deba someterse la pervivencia de una modalidad televisiva, ex lege, a la de otra.

En el otorgamiento de la prórroga, que corresponde al Consejo de Gobierno (art. 22.3 DATLO), habrá de valorarse el cumplimiento de las obligaciones y requisitos de la concesión y de la prestación del servicio, para lo cual se faculta a la Dirección General de Comunicación Social para requerir al interesado cuanta documentación estime conveniente (art. 22.2 DATLO).

En cuanto a la extinción de la concesión, ésta se producirá por las siguientes causas (arts. 15 LTLOT y 24 DATLO):

a) Transcurso del plazo, sin haberse otorgado su renovación.

b) Incumplimiento sobrevenido de los requisitos esenciales de la concesión señalados en los artículos 5, 10 y 13 LTLOT ${ }^{33}$.

c) Sanción firme, acordada por el órgano competente.

\footnotetext{
${ }^{33}$ Es decir, que se incumpla los modos de gestión del servicio (art. 5), los requisitos relativos a las frecuencias radioeléctricas (art. 10), así como los referentes a las condiciones del concesionario en el caso de gestión por particulares y, especialmente, el incumplimiento de la obligación de explotación directa del servicio y, por tanto, de la intransmisibilidad de la concesión (art. 13).
} 
d) Las previstas en la legislación de contratos de las Administraciones públicas ${ }^{34}$.

e) No haber iniciado, sin causa justificada, las emisiones dentro del plazo fijado en la concesión.

f) Suspensión injustificada de las emisiones durante más de quince días en el plazo de un año.

\section{La prestación del servicio de televisión local por ondas}

La intervención administrativa en la ordenación de esta actividad trasciende más allá del establecimiento del título habilitante y sus elementos caracterizadores, objetivos y subjetivos, entrando a disciplinar todo un elenco de aspectos relativos a la prestación de la misma, que van desde la imposición de unos principios informadores y una serie de obligaciones sobre el concesionario hasta la regulación tanto de los contenidos de la programación como de la publicidad. Es aquí, en la fijación del contenido de la prestación del servicio, donde se advierte el intenso régimen intervencionista de una actividad que, por otro lado, constituye la materialización del ejercicio de los derechos y libertades consagrados en el artículo 20 CE en el campo de la comunicación audiovisual.

\subsection{Los principios informadores de la actividad}

Es tradicional en la ordenación de los medios audiovisuales el establecimiento de un catálogo de principios a los que ha de sujetarse el funcionamiento de los mismos, declaración que tiene su punto de partida en el artículo 4 ERTV, y que luego se incorporará a casi todo el elenco de normas reguladoras de la actividad televisiva, incluida la televisión local por ondas ${ }^{35}$. En este sentido se dirige el tenor del artículo 5 DATLO ${ }^{36}$, que

\footnotetext{
34 Vid. artículos 111 y 167 TRLCAP.

35 Vid. M. J. Rozados Oliva, La televisión local por ondas, op. cit., p. 203.

${ }^{36}$ Artículo 5 DATLO: «La prestación del servicio de televisión local por ondas terrestres se inspirará en los siguientes principios:
}

1. La objetividad, veracidad e imparcialidad de las informaciones.

2. La separación entre informaciones y opiniones, la identificación de quienes sustentan estas últimas y su libre expresión con los límites previstos en el apartado 4 del artículo 20 de la Constitución Española.

3. El respeto al pluralismo político, religioso, social y cultural. 
viene a reproducir el listado de principios recogidos en el artículo 6 LTLOT. Se ha polemizado acerca de su carácter, bien por considerar que no son más que derivación de preceptos constitucionales ${ }^{37}$, bien por la discusión de si son principios propios de la comunicación audiovisual ${ }^{38}$ o si son reflejo de la condición de servicio público, sin la cual no habrían de ser de obligado cumplimiento ${ }^{39}$. En cualquier caso, la inclusión en este caso de las referencias al fomento y defensa de la cultura y los valores locales reflejan la verdadera finalidad que persigue el reconocimiento de un modelo de televisión propio de la esfera local, diferenciado del resto de modalidades por la atribución a la misma de una función de vertebración de la sociedad local, sirviendo de cauce para la expresión de sus particularidades, para la integración de sus grupos sociales y para satisfacer las necesidades de información que, de otro modo, no se verían cubiertas.

Lejos de poseer un carácter meramente declarativo, su eficacia se refuerza con la reiterada alusión a los mismos a lo largo de la normativa

4. El respeto al honor, a la intimidad personal y familiar, a la propia imagen y a todos los derechos y libertades reconocidos por la Constitución.

5. La protección de la juventud y de la infancia, de acuerdo con lo que establece el Capítulo IV de la Ley 25/1994, de 12 de julio, por la que se incorpora al ordenamiento jurídico la Directiva 89/552/CEE, sobre la coordinación de disposiciones legales, reglamentarias y administrativas de los Estados miembros relativas al ejercicio de actividades de radiodifusión televisiva.

6. El respeto al derecho de igualdad reconocido en el artículo 14 de la Constitución.

7. El fomento y la defensa de la cultura e intereses locales, así como la promoción de la convivencia, impulsando, a este efecto, la participación de los grupos sociales del ámbito territorial de cobertura correspondiente.

8. El fomento de la conciencia de identidad andaluza a través de la difusión de los valores culturales y lingüísticos del pueblo andaluz en toda su riqueza y variedad.

9. La protección de la dignidad y de los derechos de la mujer y la promoción efectiva de la igualdad sin distinción de sexo.

10. El fomento de comportamientos tendentes a la correcta utilización de los recursos naturales y a la preservación del medio ambiente.»

37 Vid. G. Fernández Farreres, El paisaje televisivo en España, Aranzadi, Madrid, 1997, p. 109; también en «La televisión local por ondas terrestres, Ordenación de las Telecomunicaciones, Cuadernos de Derecho Judicial, CGPJ, Madrid, 1997, p. 148.

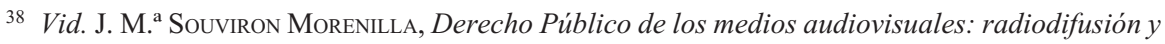
televisión, Comares, Granada, pp. 423-437.

39 Posición que mantienen De la QuadRa-SALCEdo («Los servicios televisivos», en Régimen jurídico de los servicios públicos, Cuadernos de Derecho Judicial, CGPJ, Madrid, 1997, p. 367) y Chinchilla («El régimen jurídico de las telecomunicaciones. Introducción», en Ordenación de las Telecomunicaciones, Cuadernos de Derecho Judicial, CGPJ, Madrid, 1997). 
aplicable, debiendo tenerse en cuenta el compromiso de su cumplimiento como uno de los criterios a utilizar en la adjudicación de las concesiones [art. 15.d) DATLO] y, consecuentemente, constituyendo su observancia una de las obligaciones del concesionario [art. 22.e) DATLO], de tal modo que se atribuye al Pleno municipal el deber de velar por su cumplimiento (art. 8.3 DATLO, art. 12 LTLOT). Su incumplimiento, por otra parte, supone la comisión de una infracción muy grave, sancionable con una multa de hasta diez millones de pesetas [art. 16.2.a) LTLOT].

\subsection{La regulación de los contenidos}

Si algo resulta inherente al desarrollo de la actividad de televisión, en tanto que manifiesta de manera clara la interconexión entre la libertad de empresa y la libertad de expresión, es la capacidad de elegir la estructuración de la oferta televisiva dirigida al público, es decir, la libertad de programación. Ésta, sin embargo, no posee un contenido ilimitado por cuanto el ordenamiento jurídico actúa sobre la misma a través de la regulación de algunos aspectos esenciales de la configuración de dicha programación ${ }^{40}$. En el caso de la televisión local por ondas, se introducen unas medidas que tienen como objetivo acentuar el carácter local de la emisora: por un lado, imponiendo unas cuotas de producción propia en el conjunto de la programación, y, de otro, estableciendo unos límites a la emisión en cadena.

\section{a) Las cuotas de programación propia}

La televisión local quedó al margen del cumplimiento de las cuotas de emisión de programas de origen comunitario impuestas por la Directiva 89/552/CEE, del Consejo, de 3 de octubre, cuya incorporación a nuestro ordenamiento se produjo por vía de la Ley 25/1994, de 12 de julio, al disponer el artículo 3.5 de esta última (introducido por la Ley 22/1999, de 7 de junio) que dichas cuotas no son de aplicación «a las emisiones de televisión de cobertura local que no formen parte de una red nacional». La imposibilidad de formación de cadenas de televisión como resultado de la agrupación de emisoras locales, previstas en nuestro ordenamiento sobre la televisión local, como ya vimos, producen la plena aplicabilidad de esta disposición en todos los supuestos. Esta exclusión tiene sentido desde la perspectiva en que los intereses necesitados de protección, por un lado, $\mathrm{y}$

40 Para Laguna (Régimen jurídico de la televisión privada, p. 249) «estas limitaciones han de ser necesarias y proporcionadas» $\mathrm{y}$, en todo caso, han de permitir al emisor decidir el contenido, la forma y la hora de los programas. 
de fomento, por otro, son bien distintos. Por ello, se reconoce igualmente en el propio artículo 3.5 Ley 25/1994 que «las Comunidades Autónomas podrán introducir normas de contenido equivalente... con objeto de promover la producción audiovisual en su lengua propia, en los servicios de televisión local bajo su competencia». A tal efecto, el artículo 19 DATLO dispone que la programación de las televisiones locales habrá de ser cubierta, al menos en un 50 por 100, por contenidos producidos por la propia emisora, contándose como tales hasta un cincuenta por ciento de programación coproducida o realizada por terceros en Andalucía.

\section{b) La prohibición de emisión en cadena}

El pretendido reforzamiento del carácter local se incrementa, en relación a los contenidos de la programación, con la inclusión de una cláusula de prohibición de emisión en cadena en el artículo 7 LTLOT, disponiendo a tal efecto el apartado 31 de dicho precepto que «se entenderá que emiten en cadena aquellas televisiones locales que emitan la misma programación durante más del 25 por 100 del tiempo total de emisión semanal, aunque sea en horario diferente». Esta medida fue incorporada al Derecho andaluz, primero por vía de la remisión a la norma estatal en el artículo 6.1 DATLO y, posteriormente, en la reforma llevada a cabo por el Decreto 27/2001, de 13 de febrero, incorporando un apartado $3 .^{\circ}$ al artículo 6 DATLO, especificando en los mismos términos qué ha de entenderse por emisión en cadena.

Esta coincidencia en la programación que, como certeramente señala MUÑOZ MACHADO ${ }^{41}$, pudiera constituir la «forma normal de formar cadenas», puede darse, a juicio de este autor, bien mediante el establecimiento de una conexión para ofrecer el mismo programa en idéntico momento (ya sea en directo o previamente grabado), o bien en diferente día de la semana u hora de emisión (en este caso, sólo espacios grabados). Esta limitación, sin embargo, como advierte DE CÁCERES, parece ser más restrictiva de lo que realmente es en cuanto al funcionamiento cotidiano de la televisión local y el diseño de su programación, ya que bastaría una simple operación matemática para concluir que, en una programación de veinticuatro horas, cabrían hasta seis horas diarias de emisión en cadena dentro de los límites señalados ${ }^{42}$.

${ }^{41}$ Vid. S. MuÑoz Machado, Servicio público y mercado. III. La televisión, Civitas, Madrid, 1998, p. 54.

42 Vid. R. De Cáceres y CAsillas, «La Ley de Televisión Local por Ondas de 22 de diciembre de 1995», en Derecho de las Telecomunicaciones (Coord. Cremades García), La Ley-Ministerio de Fomento, Madrid, 1997, p. 593. 
Esto es lo que permite que, en la actualidad, sean cada vez más frecuentes no sólo la emisión de una programación ciertamente similar, sino, por ejemplo, la elaboración y emisión de programas informativos entre distintas emisoras. La cuestión ha de centrarse en analizar hasta qué punto esta medida es efectiva. Podría darse la circunstancia (habitual por otra parte) de que varias televisiones locales se agruparan para comprar los derechos de emisión de una serie de películas y programas con objeto de emitirlos en semanas alternativas, con lo que se podría dar el caso que hubiera una coincidencia superior incluso al 25 por 100 de la programación, pero al darse ésta en semanas diferentes se salvaría la prohibición. Por otro lado, esta alternativa de emitir programas comunes, a juicio de MuÑOZ MACHADO, ampliaría el espectro de la potencial publicidad, al abrirse a posibles anunciantes que operen en el marco del territorio concreto de emisión comunitaria, y no sólo en el local ${ }^{43}$. Por ello es importante que esta prohibición no sea absoluta incluso para la viabilidad económica de las emisoras, pues permite una reducción de los gastos de producción. Esta razón nos lleva a considerar que la línea a seguir ha de ser, precisamente, la ampliación del porcentaje de programación que puede ser compartida ${ }^{44}$.

Por otro lado, la prohibición de emisión en cadena contenida en el artículo 7 LTLOT no tiene carácter absoluto, al prever en su apartado 41 que «no obstante lo anterior, las Comunidades Autónomas competentes podrán autorizar, previa conformidad de los plenos de los Municipios afectados, emisiones en cadena en atención a características de proximidad territorial y de identidades sociales y culturales de dichos Municipios. En tal supuesto se requerirá la conformidad de los gestores del servicio». Esta facultad de las Comunidades Autónomas, el establecerse como excepción al régimen de limitación establecido con carácter general en el apartado anterior, entendemos que se refiere a una ampliación de la cuota de programación conjunta por encima de los límites señalados en el mismo.

\footnotetext{
43 Vid. S. Muñoz Machado, Servicio público y mercado. III. La televisión, Civitas, Madrid, 1998, p. 54.

${ }^{44}$ Ya en la pasada legislatura, y tras el fracaso del Proyecto de Ley de Reforma de la LTLOT de 1997, se gestó la presentación de un nuevo Proyecto de Ley en el que se incrementaba la posibilidad de emitir en cadena hasta el 50 por 100 de su programación, con la idea de ampliar con ello su ámbito de cobertura, de modo que pudieran convertirse en televisiones comarcales, según manifestó Ana Mato, portavoz del PP en materia de telecomunicaciones (vid. El Mundo, 4 de diciembre de 1998). Hay que recordar que esta posición coincide en parte con la mantenida por Coalición Canaria en la presentación de enmiendas durante la tramitación parlamentaria de la vigente LTLOT, aunque en este caso el argumento se ceñía a reconocer las peculiares características del archipélago canario (vid. BOCG, Serie A, V Legislatura, n. ${ }^{\circ}$ 103-12, 21 de septiembre de 1995).
} 
La dificultad en este punto, como apunta SOUVIRON ${ }^{45}$, se encuentra en la definición de los elementos a considerar en la autorización de la emisión en cadena y, en particular, en la referencia a la «proximidad territorial» y a la posesión común de «identidades sociales y culturales». La norma andaluza poco aporta en este sentido, al limitarse de nuevo el artículo 6.2 DATLO a reproducir los criterios marcados en la norma estatal en los mismos términos fijados por ésta y, por tanto, sin concretar su contenido. Como única novedad al respecto se introducen en el artículo 6.3 DATLO los requisitos formales necesarios para obtener la autorización de emisión en cadena ${ }^{46}$. Por otra parte, en el otorgamiento de la misma habrá de valorarse positivamente que la programación de las emisoras sea de producción andaluza (art. 6.4 DATLO).

\subsection{Régimen de la publicidad}

En esta materia hay que distinguir el régimen dispuesto para la publicidad comercial y para la publicidad electoral. Con respecto a la primera de ellas, el artículo 21 DATLO se remite a la Ley 34/1988, de 11 de noviembre, General de Publicidad, y al Capítulo III de la Ley 25/1994, de 12 de julio. Con esta última remisión se equipara en nuestra Comunidad Autónoma el régimen de la publicidad de las televisiones locales con las demás televisiones de cobertura nacional, aplicándose por tanto también las disposiciones sobre los tiempos máximos de publicidad y las reglas formales sobre emisión de la misma ${ }^{47}$. En cuanto a la publicidad electoral, el régimen se contiene, de nuevo por remisión, en la LO 14/1995, de pu-

\footnotetext{
45 Vid. J. M. Souviron Morenilla, «En torno a la regulación de la televisión local por ondas terrestres y algunas cuestiones conexas», Revista de Estudios de la Administración Local y Autonómica, n. ${ }^{\circ} 269$, enero-marzo, 1996, p. 64.

46 Artículo 6.3 DATLO: «La autorización para las emisiones en cadena deberá ser solicitada por los titulares de la gestión del servicio ante la Consejería de la Presidencia, debiendo aportar los siguientes datos y documentos:
}

a) Conformidad de los gestores del servicio.

b) Televisiones locales que pretendan realizar las emisiones en cadena.

c) Características de la programación a emitir en cadena: Temática, origen de la producción y porcentaje del tiempo de emisión.

d) Acuerdo de conformidad de los Plenos Municipales.

e) Cualquier otro que contribuya a justificar la conveniencia de dicha emisión en cadena.»

47 Esta circunstancia ha sido criticada por algún autor, como FernÁNDEZ FARRERES (El paisaje televisivo en España, Aranzadi, Madrid, 1997, p. 110), para quien no resulta razonable la extensión de estas reglas también a la televisión local. 
blicidad electoral en las emisoras de televisión local por ondas ${ }^{48}$ y en la Ley 4/1999, de 11 de mayo, sobre la actividad publicitaria de las Administraciones públicas de Andalucía.

\subsection{Otras obligaciones del concesionario}

La adjudicación de la concesión para la explotación de una televisión local por ondas comporta el nacimiento de una serie de obligaciones para el concesionario. Junto a aquellas que se derivan del contenido del artículo 161 TRLCAP, exigibles en cuanto concesionario de un servicio público, y el cumplimiento de las obligaciones incluidas en la propia concesión, el artículo 22 DATLO incluye una serie de deberes, de entre los que caben destacarse los siguientes:

a) La regularidad y continuidad en la prestación del servicio

Se trata en este caso de la recepción en el marco de la televisión de principios que constituyen elementos tradicionales de la institución servicial ${ }^{49}$, y que se encuentran reconocidos en nuestro ordenamiento en el propio artículo 161.a) TRLCAP. El objetivo que se persigue con su inclusión es evitar el perjuicio que la falta de prestación del servicio pudiera ocasionar al ciudadano. Aunque esto no parece que posea la suficiente trascendencia en el campo de la televisión, el principio de regularidad tiene su traducción en la imposición de un tiempo mínimo de emisión, que es fijado en cuatro horas diarias por el artículo 19 DATLO.

Por otro lado, se pretende garantizar la continuidad impidiendo la suspensión del servicio. Así, el artículo 22.c) DATLO dispone que la emisión no podrá ser interrumpida «durante más de tres días consecutivos o quince días a lo largo de un año, sin la autorización de la Dirección General de Comunicación Social». El cumplimiento de esta obligación se refuerza a través del establecimiento como causa de extinción de la concesión la «suspensión injustificada de las emisiones durante quince dias en un año» [art. 24.f) DATLO].

\footnotetext{
48 Sobre esta cuestión, vid. M. J. Rozados Oliva, La televisión local por ondas, Comares, Granada, 2001, pp. 222-223.

49 Vid. E. García Llovet, El régimen jurídico de la radiodifusión, Marcial Pons, Madrid, 1991, p. 333; F. Sosa Wagner, La gestión de los servicios públicos locales, Civitas, Madrid, 1992, p. 96; también en Comentarios a la Ley de Contratos de las Administraciones Públicas, Cedecs, Barcelona, 1995, p. 153.
} 
b) Los deberes de información

Se incluye, por último, un interesante conjunto de obligaciones cuyo contenido se centra en el suministro por el concesionario a la Administración concedente de una detallada información sobre la marcha del servicio, en directa relación con la potestad de control sobre el mismo. De este modo, el concesionario deberá comunicar a la Administración las siguientes cuestiones (art. 22 DATLO):

- Nombramiento del Director de la emisora y su sustituto en caso de vacante, ausencia o enfermedad.

— Conservación de la programación durante doce meses.

- Presentación, antes del 15 de diciembre de cada año, del plan de programación previsto para el año siguiente, con especificación de las horas de emisión, determinación de la programación de producción propia y el período de vigencia del mismo, debiendo comunicar cualquier modificación de dicho plan.

- Presentación en los seis meses siguientes al cierre anual de cada ejercicio de una memoria justificativa de la situación económico-financiera de la emisora.

El establecimiento de estos deberes de carácter informativo sobre la marcha del servicio ha de entenderse desde la óptica de un marcado carácter intervencionista en el control del mismo. A nuestro juicio, no parece justificable la inclusión de tantos mecanismos que pudieran sujetar el ejercicio de la actividad a un excesivo control. En algún caso, como la obligatoriedad de comunicar el nombramiento del Director de la emisora y su sustituto, además de no afectar al funcionamiento del servicio, podría considerarse una injerencia en las potestades de organización y desarrollo de la actividad, que deben ser de libre decisión del concesionario. No obstante, la ausencia, junto a la imposición de estos deberes, de potestades de veto, unido a que no en vano el diseño de la programación ha de hacerse conforme a los términos de la concesión y la normativa aplicable al efecto, reduce considerablemente la relevancia de su establecimiento, aunque ciertamente puede dejar una puerta abierta a la resolución de la concesión por su incumplimiento, lo cual nos parece exagerado. 


\section{La situación de las emisoras cuyo funcionamiento es anterior al 1 de enero de 1995}

La LTLOT, en su Disposición transitoria única, estableció el régimen aplicable a las emisoras de televisión local que se encontraban emitiendo con anterioridad al 1 de enero de $1995^{50}$, distinguiendo con ello a éstas de aquéllas que habían iniciado sus emisiones con posterioridad a dicha fecha, con independencia de que el comienzo de la actividad fuera anterior o posterior a la propia entrada en vigor de la Ley, siendo reproducido este régimen por la norma andaluza (Disposición transitoria DATLO).

El establecimiento de esta medida, de carácter transitorio, encuentra su primer punto de crítica, como advierte SOUVIRON, en el tratamiento procedimental previsto para la obtención de las concesiones en el caso de las emisoras ya existentes. La dicción del apartado $3 .^{\circ}$ de la Disposición transitoria, al disponer que «la solicitud para el otorgamiento de la concesión se dirigirá por los respectivos Ayuntamientos a la Comunidad Autónoma correspondiente», provoca que la decisión de solicitar el otorgamiento o de no hacer uso de tal facultad corresponda a la Corporación Local, que igualmente podría solicitar que la concesión llevara aparejada la gestión municipal de la emisora, dejando con ello la pervivencia de una hipotética emisora de titularidad privada al amparo de la postura del municipio ${ }^{51}$.

En otro orden, ha de ser objeto de crítica, como así se ha manifestado abiertamente, la inexplicable elección de la fecha a partir de la cual se sustenta el diferente régimen ${ }^{52}$. Podría con ello producirse una situa-

\footnotetext{
${ }^{50}$ Disposición transitoria LTLOT:
}

«1. Las emisoras de televisión local que estén emitiendo por ondas terrestres con anterioridad al 1 de enero de 1995 deberán obtener, para continuar con su actividad, la correspondiente concesión con arreglo a esta Ley.

2. El otorgamiento de la concesión para la prestación del servicio se verificará previa la asignación de las frecuencias y demás características técnicas que se determinen de acuerdo con lo dispuesto en esta Ley.

3. La solicitud para el otorgamiento de la concesión se dirigirá por los respectivos Ayuntamientos a la Comunidad Autónoma correspondiente.

4. En caso de no obtenerse dicha concesión, tales emisoras dejarán de emitir en un plazo de ocho meses a contar desde la resolución del concurso.»

51 J. M. Souviron Morenilla, «En torno a la regulación...», op. cit., p. 69.

52 De este modo, para Fernández Farreres (El paisaje televisivo en España, Aranzadi, Pamplona, 1997, p. 111), la crítica viene fundada, por un lado, porque el funcionamiento de las emisoras con anterioridad a la fecha indicada nunca ha tenido cobertura jurídica y, por otro, porque «permitir el 
ción de desigualdad no justificada entre aquellas televisiones cuyas emisiones comenzaron con posterioridad a la fecha establecida y, sin embargo, con anterioridad a la entrada en vigor de la norma. El motivo que justifica esta decisión bien pudiera hallarse en evitar que la inminente aprobación de la Ley hubiera provocado el surgimiento de nuevas emisoras de televisión ante la expectativa de que un régimen transitorio permitiría su legalización sin someterse a las nuevas reglas previstas. Ello hubiera sido relativamente razonable si el tratamiento para las emisoras que funcionaban con anterioridad a la Ley hubiera sido en verdad distinto de aquellas que pretendieran ponerse en marcha con posterioridad, cuestión de la que puede dudarse a la vista del régimen transitorio finalmente aprobado.

Cuando decimos que el aparente régimen diferente no lo es tanto, no es más que porque la citada Disposición transitoria establece el deber de las emisoras a que se refiere de obtener la oportuna concesión conforme a lo dispuesto a lo largo de este cuerpo legal. Con ello puede asegurarse, sin dificultad alguna, que se encuentran sometidas por tanto a los mismos términos, al menos en lo que a la obtención del título habilitante se refiere, que cualquier emisora de televisión que hubiera iniciado su actividad en fecha posterior a la señalada ${ }^{53}$.

Si a esta circunstancia añadimos lo manifestado anteriormente en el sentido de que aún no se ha resuelto ningún proceso concesional debido a la inactividad de la Administración estatal que no ha procedido a la reserva de frecuencias necesaria con carácter previo a la convocatoria de los correspondientes concursos, podemos concluir de nuevo que, en la actualidad, todas las emisoras de televisión local por ondas se encuentran funcionando bajo las mismas circunstancias que existían con anterioridad a la LTLOT, con lo que, como de hecho ocurre, paradójicamente la propia Administración podría actuar contra las mismas en virtud de la realización de una actividad «ilegal».

\footnotetext{
funcionamiento de tales emisoras mientras no se celebre concurso alguno... no deja de ser dificilmente conciliable con las razones que justifican y legitiman la imposibilidad de desarrollar esa actividad si no media la oportuna concesión administrativa». En la misma línea se manifiesta De CÁceres («La Ley de Televisión Local por Ondas», en J. Cremades, Derecho de las Telecomunicaciones, op. cit., p. 596), quien se pregunta por qué se eligió la mencionada fecha y no el día de la promulgación de la ley, criterio a su juicio más racional.

${ }^{53}$ En esta línea se manifiesta Souviron (Derecho Público de los medios audiovisuales: radiodifusión y televisión, Comares, Granada, 1999, p. 252), para quien «la precaria situación de esas televisiones locales quedó refrendada por la Ley pese a la apariencia bonancible del texto de la Transitoria».
} 
Esta precaria situación ha sido refrendada por la Sentencia de la Audiencia Nacional de 11 de mayo de 1999, que, en relación a la disposición transitoria de la LTLOT, manifiesta que lo que hace la misma, "«de acuerdo con lo previsto en el articulado que la precede, es posibilitar la adecuación a la legalidad de las emisoras de televisión local que estuvieran emitiendo con anterioridad al 1 de enero de 1995, permitiendo que continúen su actividad, pero si obtienen la correspondiente concesión que en la misma Ley se prevé - número 1-, lo que se debe verificar, entre otras cosas, previa la asignación de frecuencias - número 2-, de tal forma que si no se obtiene dicha concesión deben dejar de emitir en un plazo determinado - número 4- Es decir, partiendo de un supuesto de ilegalidad, cual es la emisión de televisión por ondas sin concesión, exigida por el artículo 25 de la Ley 31/1987, de 18 de diciembre, de Ordenación de las Telecomunicaciones, se permite la adecuación a la ley, cumpliendo ciertos requisitos. No se legalizan situaciones anteriores, lo único que se hace es permitir una adecuación a la legalidad. Que, además, y en su caso, podrá o no tener lugar» (fundamento jurídico $4 .^{\circ}$ ).

Una primera lectura de este pronunciamiento judicial nos podría llevar a entender que en él se contiene una interpretación literal y restrictiva de la disposición transitoria de la LTLOT que hace ineficaz en la práctica su establecimiento, toda vez que, volvemos a decir, inserta ambas situaciones, anterior y posterior a la fecha indicada, bajo el mismo régimen. Sin embargo, a pesar de su no muy acertado criterio, encierra alguna clave interesante, como a continuación veremos.

En este punto parece necesario hacer una relectura del régimen transitorio en la necesidad de encontrar en el mismo una verdadera situación de transición que impida declarar la ineficacia de su establecimiento. Hemos de partir de la idea que la previsión de un régimen transitorio ha de tener como objetivo principal, en un caso como el presente, en que se lleva a cabo una ordenación de una actividad que se viene realizando con la ausencia de la cobertura legal necesaria, permitir la adecuación de las situaciones anteriores al régimen que pretende instaurarse, sin dejar de reconocer por tanto que su existencia ha de ser contemplada por la norma, de uno u otro modo.

Pues bien, entendemos que puede hallarse una interpretación que permita cumplir con el objetivo de dotar de un cauce de «transición a la legalidad» («adecuación a la legalidad» lo llama la Sentencia referida) a las emisoras que se hallaban emitiendo con anterioridad al 1 de enero de 1995, que, como vimos, es el momento a partir del que han de desplegarse los efectos jurídicos de la disposición transitoria. 
Hay que tener en cuenta que, para estas emisoras, a la vez que se les obliga a obtener la oportuna concesión con arreglo a lo previsto en la LTLOT, se dispone que, «en caso de no obtenerse dicha concesión, tales emisoras dejarán de emitir en un plazo de ocho meses a contar desde la resolución del concurso» (apartado $4 .^{\circ}$ de la Disposición Transitoria LTLOT). Esta disposición contiene a nuestro entender un pronunciamiento sumamente importante a la hora de determinar la situación en la que se encuentran actualmente cientos de emisoras de televisión local por ondas.

La interpretación de este precepto ha de conectarse con el objetivo antes señalado. El legislador, consciente de que los adjudicatarios de los concursos serían en buena parte aquellas emisoras, públicas o privadas, que ya se encontraban operando, reconoce lo ilógico que sería que cesaran sus emisiones durante el proceso concesional, para su reanudación posterior, con el grave perjuicio que ello ocasionaría desde el punto de vista financiero, a la vez que dejaría a los usuarios del mismo (los ciudadanos de cada municipio) sin el disfrute de este servicio. Pero es que, además, prevé incluso que el operador actual no sea el adjudicatario final del concurso, obligándole en tal caso a cesar en sus emisiones en el plazo de ocho meses. De esta manera admite la existencia de un período de emisión por quien no ha resultado seleccionado para la prestación del servicio.

Con ello, a nuestro juicio, se produce una cierta habilitación legal para el ejercicio de la actividad por las emisoras que se encuentran dentro del ámbito de aplicación de la Disposicion Transitoria. No puede interpretarse de otro modo la misma, pues en caso contrario el legislador podría haber dispuesto, como por otra parte hubiera sido plenamente lícito, el obligatorio cese de las emisoras existentes hasta la tramitación de los procesos concesionales, o su cese inmediato una vez finalizados éstos, o incluso podría haber omitido cualquier pronunciamiento, lo que hubiera provocado implícitamente el mismo resultado, así como cualquier tratamiento diferenciado de las emisoras existentes (ahora bien, otra cuestión es que esta situación de provisionalidad que admite la permisividad en el funcionamiento de estas emisoras se prolongue en el tiempo, más allá de lo que hubiera sido no sólo deseable, sino incluso razonable).

En contra de esta opinión parece situarse el pronunciamiento de la $\mathrm{Au}-$ diencia Nacional en la Sentencia mencionada, para la que no consta «ni explícita ni implícitamente... la existencia de una autorización legal, dado que el párrafo 4 de la misma sólo permite transitoriamente la emi- 
sión en caso de no obtenerse la concesión, estableciendo el párrafo primero el deber de obtener la concesión con arreglo a la ley» (fundamento jurídico $5 .^{\circ}$ ). Ciertamente, la LTLOT no «legaliza» las emisoras anteriores en el sentido de dotarlas de la autorización necesaria para funcionar. Lo que en realidad hace, como la propia Sentencia reconoce, es permitir su funcionamiento mientras se llevan a cabo los correspondientes concursos). ¿En qué consiste si no la «adecuación a la legalidad»? Como igualmente se expresa, y no hay lugar a dudas, se permite la emisión transitoriamente con posterioridad a la celebración del concurso, y durante un período concreto. No parece muy acertado pensar que, en dicho caso, el operador ha de cesar en las emisiones que, sin embargo, podrán continuar, en el caso de no obtener la concesión, durante los ocho meses siguientes a la adjudicación definitiva de la misma.

La admisión de las emisiones, con carácter transitorio, mientras se llevan a cabo los procesos concesionales, es la solución adoptada con mayor claridad en la normativa castellano-manchega, al disponer en el apartado 4 de la Disposición transitoria del Decreto 54/2000 que «transitoriamente, y hasta la fecha en que se otorguen las correspondientes concesiones administrativas, las emisoras de televisión local por ondas terrestres en funcionamiento con anterioridad a la entrada en vigor de la presente norma podrán seguir en funcionamiento y emitir en su correspondiente ámbito de cobertura». Sorprende, sin embargo, que esta disposición haya sido objeto, junto con otras de la misma norma, de la interposición de un conflicto positivo de competencias por el Gobierno de la Nación (que no olvidemos es de distinto signo político que el Gobierno autonómico, a la sazón de la misma opción política que promovió la aprobación de la LTLOT), lo que ha provocado la suspensión de su eficacia ${ }^{54}$.

La interpretación que proponemos se ajusta, a nuestro entender, a las previsiones transitorias de la LTLOT, alcanzando con ello un doble objetivo: por un lado, permite que el régimen establecido se corresponda con unas auténticas normas transitorias, sin que su probablemente desafortunada redacción le prive de eficacia y, del mismo modo, permita la adecuación a la legalidad de las emisoras que se encuentran dentro de su ám-

\footnotetext{
${ }^{54}$ Conflicto positivo de competencias n. ${ }^{\circ} 2122 / 2000$ planteado por el Gobierno contra determinados preceptos del Decreto 54/2000, de 21 de marzo, de Castilla La-Mancha, y admitido a trámite por Providencia del Tribunal Constitucional, que determinó la suspensión de la eficacia de los preceptos impugnados, entre los que se encuentra la mencionada disposición transitoria, desde la formalización del conflicto el 11 de abril de 2000 (vid. BOE n. ${ }^{\circ} 113$, de 11 de mayo de 2000). En la tramitación de este conflicto, el Tribunal Constitucional, mediante Auto de 3 de octubre de 2000, ha decidido levantar la suspensión de los preceptos impugnados, manteniéndola, sin embargo, sobre la Disposición transitoria (vid. BOE n. ${ }^{\circ} 245$, de 12 de octubre de 2000).
} 
bito de aplicación; y, por otro, posibilita que el funcionamiento de éstas últimas encuentre en dichas previsiones el marco de su adecuación a la legalidad, manteniendo de modo provisional una habilitación de la propia Ley para la continuidad de las emisiones hasta la finalización de los procesos concesionales, lo que traería como consecuencia, asimismo, la imposibilidad de considerar que las mismas se encuentran en situación completamente «ilegal».

\section{CONCLUSIONES}

Que la televisión local por ondas se trata de un medio de comunicación audiovisual que cuenta con una considerable implantación y que goza de un notable arraigo en la vida cotidiana de una gran parte de la sociedad son afirmaciones que pueden comprobarse fácilmente. Que su regularización es necesaria, no ya sólo por el simple hecho de sujetar su desarrollo a unas reglas comunes, sino fundamentalmente por evitar el mantenimiento de una situación caótica que afecta a todo el conjunto de aspectos relacionados con la ordenación de la actividad televisiva (ocupaciones ilegales e incontroladas del espectro radioeléctrico, incumplimiento de las normas sobre publicidad, programación e, incluso, sobre protección de menores, etc.), es un razonamiento que se impone con un simple viaje, mando a distancia en mano, por el universo de la oferta de canales que recibimos en nuestro receptor de televisión.

El marco jurídico necesario está ahí, vigente, esperando llevar a buen puerto sus determinaciones. La labor, por tanto, de creación de la normativa precisa ha dado ya el primer paso, no sólo desde el Derecho estatal, sino también desde el ejercicio de las competencias autonómicas en algunos casos. Es el momento de plantear, entonces, si el modelo diseñado es válido para afrontar la realidad a la que se dirige, si es preciso abordar su reforma o, simplemente, ejecutar sus previsiones. El análisis de las normas aplicables y su confrontación con el escenario actual nos lleva, indefectiblemente, a propugnar la primera opción. El modelo es insuficiente, excesivamente municipalista, alejado de los tiempos que corren en el campo de la comunicación y, por ello, casi anacrónico. Dado el tiempo que ha transcurrido ya desde el surgimiento espontáneo de este fenómeno, bajo parece el precio que habría de pagarse en espera de una debida reforma.

Ya refiriéndonos a la norma andaluza, hemos visto en este trabajo cómo su contenido se reduce, básicamente, a seguir las determinaciones 
de la norma estatal. Son muchas las cuestiones sobre las que bien pudiera haber entrado. Desde la definición de los criterios para la ampliación del ámbito de cobertura y para la autorización de la emisión en cadena, hasta el pronunciamiento acerca de la financiación de las emisoras o el establecimiento de unas reglas propias en materia de publicidad que diferencien a esta modalidad televisiva del resto, pasando por un desarrollo de los distintos elementos del ejercicio de la potestad sancionadora que contribuyan a garantizar el cumplimiento de las disposiciones. Sin embargo, se ha optado, como ha ocurrido en otras Comunidades, por regular principalmente los aspectos formales del otorgamiento de las concesiones, incluyendo como únicas y verdaderas novedades (mención aparte de la introducción de algunos principios inspiradores) el endurecimiento de los requisitos para reunir la condición de concesionario y el establecimiento de una serie de deberes de información de éste hacia el órgano autonómico, muestra de una excesiva preocupación quizá por controlar más a los sujetos que al propio objetivo que ha de perseguirse en la ordenación de una actividad que no es más que el ejercicio, en la esfera local, de los derechos y libertades consagrados constitucionalmente en el artículo 20 $\mathrm{CE}$. Ahora bien, justo es reconocer que las limitaciones e insuficiencias del modelo estatal poco margen han dejado para la innovación y que, sobre todo, con el desarrollo de este instrumento normativo se aprecia un voluntarismo por solucionar la problemática de esta modalidad televisiva del que bien pudiera tomar ejemplo la Administración estatal. 


\section{Jurisprudencia}


